\title{
Protective Effect Of P-Coumaric Acid As Free Oxygen Radical Scavenger In Experimental Renal Ischemia-Reperfusion Model
}

\section{Deneysel Renal İskemi Reperfüzyon Modelinde Serbest Oksijen Radikali Temizleyici Olarak P-Kumarik Asit’in Koruyucu Etkisi}

\author{
Ayhan Tanyeli', Derya Güzel² \\ ${ }^{1}$ Atatürk Üniversitesi Tıp Fakültesi, Fizyoloji A.D., Erzurum \\ ${ }^{2}$ Sakarya Üniversitesi Tıp Fakültesi, Fizyoloji A.D., Sakarya \\ Yazışma Adresi / Correspondence: \\ Derya Güzel
}

Sakarya Üniversitesi Tıp Fakültesi, Fizyoloji A.D., Sakarya

T: +90 5541936443 E-mail: deryaguzel@sakarya.edu.tr

Geliş Tarihi / Received : 31.08.2018 Kabul Tarihi / Accepted : 06.09.2018

\begin{abstract}
Aim The aim of this study is to evaluate the antioxidant effect of $p$-Coumaric Acid ( $p$-CA) on tissue damage due to ischemia-reperfusion in rat kidney tissue. ( Sakarya Med J 2018, 8(3):625-631)

Methods Thirty-two 12-16 week-old Wistar Albino female rats weighing 200-250 g were used in this study. Rats underwent right nephrectomy intraperitoneally with an incision made in the dorsal region under ketamine $(75 \mathrm{mg} / \mathrm{kg})$ and xylazine $(8 \mathrm{mg} / \mathrm{kg})$ anesthesia. These rats were randomly divided into four groups in equal numbers $(n=8)$. Groups were classified as the sham $(S)$, renal ischemia-reperfusion $(R-I R)$, $50 \mathrm{mg} / \mathrm{kg} \mathrm{p}$-CA with R-IR (p-CA 50), and $100 \mathrm{mg} / \mathrm{kg}$ p-CA with R-IR (p-CA 100). After the dorsum of all rats was opened and the right nephrectomy was performed, all groups except sham were clamped on the left renal artery and ischemia and reperfusion protocol was performed. P-CA was administered in two doses, $60 \mathrm{~min}$ before ischemia and $30 \mathrm{~min}$ before reperfusion. Total antioxidant levels (TAS), total oxidant level (TOS), superoxide dismutase (SOD), malondialdehyde (MDA), and myeloperoxidase (MPO) levels of left kidney were measured spectrophotometrically, and oxidative stress index (OSI) was calculated.

Results TOS, MDA, MPO, and OSI values increased in R-IR group compared to $S(p<0.01)$, while TAS and SOD values decreased. Increase in TAS and SOD values, a decrease in TOS, MDA, MPO, and OSI values were observed in P-CA applied groups $(p<0.05)$.

Conclusion Our findings indicate that $p$-CA administration in renal ischemia-reperfusion injury may play a role in protecting tissue by reducing oxidant damage.

Keywords p-coumaric acid; renal ischemia-reperfusion injury; oxidative stress.
\end{abstract}

Amaç Bu çalışmanın amacı, sıçan böbrek dokusunda iskemi-reperfüzyona bağlı doku hasarı üzerine $p$-kumarik asit ( $p$-CA)'in antioksidan etkisini değerlendirmektir. ( Sakarya Tıp Dergisi 2018, 8(3):625-631 ).

Yöntem 12-16 haftalık 200-250 gr otuz iki adet Wistar Albino cinsi dişi sıçan temin edildi. Sıçanlara intraperitonal olarak ketamine $(75 \mathrm{mg} / \mathrm{kg}) \mathrm{ve}$ xylazine $(8 \mathrm{mg} / \mathrm{kg}$ ) anestezisi altında sırt bölgesinden yapılan bir kesi ile sağ nefrektomi uygulandı. Bu sıçanlar randomize olarak dört gruba eșit olarak bölündü ( $\mathrm{n=8)}$. Gruplar; sham (S), renal iskemi-reperfüzyon (R-IR), R-IR ile $50 \mathrm{mg} / \mathrm{kg} p$-kumarik asit (p-CA 50) ve R-IR ile 100 $\mathrm{mg} / \mathrm{kg}$ p-kumarik asit (p-CA 100) uygulanan grup olarak sınıflandırıldı. Sham hariç diğer gruplardaki sıçanların sırt bölgesi açılıp sağ nefrektomi yapıldıktan sonra sol renal arter klemplenerek iskemi ve reperfüzyon protokolü uygulandı. P-kumarik asit iskemiden $60 \mathrm{dk}$ önce ve reperfüzyon bașlangııından $30 \mathrm{dk}$ önce olmak üzere iki doz șeklinde uygulandı. İșlemler tamamlandıktan sonra sol böbrek total antioksidan düzeyi (TAS), total oksidan düzeyi (TOS), süperoksit dismutaz (SOD), malondialdehit (MDA) ve myeloperoksidaz (MPO) seviyeleri spektrofotometrik yöntemlerle ölçüldü. Oksidatif stres indeksi (OSI) hesaplandı.

Bulgular R-IR grubunda S ile karşılaştıııldığında TAS ve SOD değeri düşerken, TOS, MDA, MPO ve OSı değerleri yükseldi ( $p<0.01)$. P-CA uygulanan gruplarda TAS ve SOD değerinde yükselme, TOS, MDA ve MPO değerlerinde ise düşme gözlendi. $(p<0.05)$.

Sonuç Bulgularımız, renal iskemi reperfüzyon hasarında p-CA uygulamasının oksidan hasarı azaltarak dokunun korunmasında rol oynayabileceğini göstermektedir. 
Sakarya Medical Journal 2018;8(3):625-631

TANYELi et al. P-Coumaric Acid in Experimental Rena Ischemia-Reperfusion Mode

\section{Introduction}

Ischemia/reperfusion (IR) damage is characterized by restraint of blood supply to tissues and subsequent restoration of oxygenation with blood flow. ${ }^{1}$ The damage is further complicated by the release of oxygen-derived free radicals into the tissue, although reperfusion is necessary for ischemic tissue survival. ${ }^{2}$ Renal ischemia-reperfusion (R-IR) injury may be resulted in due to renal transplantation, shock, sepsis and surgical procedures despite great clinical efforts. ${ }^{3}$ IR injury is the primary cause of high mortality in acute renal insufficiency, the R-IR model in fighting against this injury is used in experimental studies widely. ${ }^{4,5}$

Acute renal insufficiency occurs in approximately 5\% of hospitalized patients and $30 \%$ of patients in intensive care units. ${ }^{5,6}$ Although the pathophysiology of R-IR injury is complex; basically increased inflammation plays a major role in the responsibility. ${ }^{7}$ Severe responses in ischemia, including activation of reactive oxygen species (ROS), neutrophils, inflammatory mediators such as cytokines and adhesion molecules, play a role in the onset of R-IR injury. ${ }^{1}$ In addition, R-IR causes an inflammatory cascade contributing to even more damage, thus control of inflammatory reactions on R-IR damage is often considered a therapeutic target to protect kidney. ${ }^{8,9}$

Post-ischemic reperfusion is characterized by elevated ROS with inflammation, leukocyte infiltration, neutrophil accumulation as a consequence of tissue reoxygenisation disorders. ROS production and toxic molecules interact with cellular molecules and this interaction causes to cellular damage. ${ }^{10}$ ROS causes to lipid peroxidation and MDA, the end product of lipid peroxidation, is a biomarker of tissue damage..$^{10}$ Oxidative mechanisms lead to tissue damage when they are dominant for any reason. ${ }^{11}$ Lipid peroxidation is an autocatalytic cascade that leads cell death with the increase of cell membrane permeability leading to oxidative damage to cellular membranes. ${ }^{12}$ MDA is a good indicator of lipid peroxidation. ${ }^{13-15}$ Another parameter known as an oxidant in the cell is the MPO enzyme. ${ }^{16,17}$ MPO is secreted by neutrophils and used as a marker of neutrophil activation which is caused by IR damage. ${ }^{10}$ In one study, serum liver MDA levels and liver tissue MPO activity were increased in the IR model in rats. ${ }^{18}$

p-CA is a phenolic acid of the hydroxycinnamic acid family. ${ }^{19}$ It is synthesized from phenylalanine and tyrosine. $p$-CA is commonly found in fruits, vegetables, grains, and rye. ${ }^{20} p-C A$ is a well-documented antioxidant known to have radical scavenging activity. ${ }^{21,22}$ Yue Y. et al. showed that $p$-CA reduces oxidative stress. ${ }^{23}$ It has been demonstrated that $p$-CA has antifungal, antiviral, anti-melanogenic, antioxidant, and anti-inflammatory effects. ${ }^{24,18}$ Therefore, in this study, the effects of $p$-CA on oxidant/antioxidant balance in the R-IR model were investigated via biochemical measurements.

\section{Materıals And Methods \\ Experimental Protocol}

12-16 week-old 200-250 g weight Wistar Albino female rats obtained from Atatürk University Experimental Animal Laboratory were fasted overnight for ischemia and reperfusion experiments and were only allowed to reach the water. Rats underwent right nephrectomy with an incision made in the dorsal region under ketamine $(75 \mathrm{mg} / \mathrm{kg})$ and xylazine $(8 \mathrm{mg} / \mathrm{kg})$ administered intraperitoneally. Experimental research was performed on the left kidney. The animals were randomly divided into 4 groups with 8 animals in each group. 
Group I (Sham Control): Experimental animals were opened from the right and left sides of the dorsal regions and nephrectomy was performed on the right without any application on the left except incision, and then both sides were covered with 3.0 silk sutures.

Group II (Ischemia-reperfusion): The left renal artery was clamped after opening the dorsum of the rats and application of right nephrectomy. The left kidney was subjected to 1 hour of ischemia followed by 24 hours of reperfusion.

Group III and IV (Ischemia-reperfusion + p-CA $50 \mathrm{mg} / \mathbf{k g}$ and $\mathbf{1 0 0 ~} \mathrm{mg} / \mathbf{k g}$ ): In addition to the surgical procedures in Group II, $50 \mathrm{mg} / \mathrm{kg}$ and $100 \mathrm{mg} / \mathrm{kg}$, $\mathrm{p}$-CA was administered by oral gavage to rats, respectively 1 hour before ischemia and 30 minutes before the onset of reperfusion.

After the animals were sacrificed, kidney tissues were stored in a $-80{ }^{\circ} \mathrm{C}$ freezer for biochemical measurements.

\section{Biochemical methods}

Phosphate buffer was added to the tissues for analysis to form $10 \%$ homogenate and homogenized on the ice at 12,000 rpm for 1-2 minutes (IKA, Germany). Homogenate tissue samples were centrifuged at $+4{ }^{\circ} \mathrm{C}$ for 30 minutes at $5000 \mathrm{rpm}$ to obtain the supernatant. The resulting supernatants were tested for TAS, TOS, SOD, malondialdehyde (MDA), and myeloperoxidase (MPO) levels.

MDA levels of homogenate samples were analyzed using the method described by Ohkawa et al.25 TAS (Rel Assay Diagnostics) and TOS (Rel Assay Diagnostics) analyses were performed using commercial kits. OSI was calculated by the following formula.

OSI $=\left(\left[\right.\right.$ TOS, mmol H2O2 equivalent / L] / [TAS, mmol Trolox equivalent / L] x 10)). ${ }^{26}$

MPO was based on the kinetic measurement of the absorbance at $460 \mathrm{~nm}$ wavelength of the yellowish-orange complex form, which is the result of oxidation of MPO and o-dianisidine in the presence of hydrogen peroxide ( $\mathrm{H} 2 \mathrm{O} 2$ ). SOD was calculated after reacting with tetrazolium salt to form formazan dye by measuring the degree of inhibition of this reaction at $560 \mathrm{~nm}$ wavelength in the spectrophotometer when the effect of the superoxide SOD enzyme resulting from the enzymatic reactions was insufficient. ${ }^{27}$

\section{Statistical Analysis}

SPSS 21.0 program (SPSS Inc. and Lead Tech Inc., Chicago, USA) was used for statistical analysis. The data were expressed as the mean \pm standard deviation. In the comparison of the parameters, the difference between the two groups was evaluated by the Mann Whitney $U$ test and $p<0.05$ was considered statistically significant.

\section{Results}

No morbidity and mortality were observed in rats during experimental applications. In the R-IR group, the level of TAS (from 2.076 \pm 0.326 to $1.311 \pm 0.166, p=0.000$ ) and SOD (from $478.139 \pm 82.335$ to $262.908 \pm 13.744, p=0.000$ ) decreased while TOS (from $6.546 \pm 0.398$
Sakarya Medical journal 2018;8(3):625-631

\section{TANYELi et al.} P-Coumaric Acid in Experimental Renal Ischemia-Reperfusion Model 
Sakarya Medical Journal 2018;8(3):625-631

TANYELi et al. to $9.720 \pm 0.878, p=0.000$ ), OSI (from $0.322 \pm 0.052$ to $0.751 \pm 0.104, p=0.000$ ), MPO (from $39430.418 \pm 5647.174$ to $70208.207 \pm 27307.594, p=0.008$ ), and MDA (from $77.734 \pm 7.394$ to $121.657 \pm 7.633, p=0.000)$ increased.

When p-CA50 was compared with sham group; SOD (from $478.139 \pm 82.335$ to $408.016 \pm 38.015$, $p=0.002$ ) decreased, while TOS (from $6.546 \pm 0.398$ to $7.352 \pm 0.643, \rho=0.009$ ), OSI (from $0.322 \pm 0.052$ to $0.412 \pm 0.082, p=0.020$ ), MPO (from $39430.418 \pm 5647.174$ to 48426.019 $\pm 3309.833, \rho=0.049$ ), and MDA (from 77.734 \pm 7.394 to $85.901 \pm 7.741, \rho=0.046$ ) increased.

Then, when $p$-CA 50 was compared with R-IR group; TAS (from $1.311 \pm 0.166$ to $1.829 \pm .0 .282$, $p=0.001$ ) and SOD (from 262.908 \pm 13.744 to $408.016 \pm 38.015, p=0.000$ ) increased, while TOS (from $9.720 \pm 0.878$ to $7.352 \pm 0.643, p=0.000$ ), OSI (from $0.751 \pm 0.104$ to $00.412 \pm 0.082$, $p=0.000$ ), MPO (from 70208.207 \pm 27307.594 to $48426.019 \pm 3309.833, p=0.042$ ), and MDA (from $121.657 \pm 7.633$ to $85.901 \pm 7.741, \rho=0.000$ ) decreased.

Lastly, when $p$-CA 100 was compared with R-IR; TAS (from $1.311 \pm 0.166$ to $2.057 \pm 0.167$, $p=0.000$ ) and SOD (from $262.908 \pm 13.744$ to $445.378 \pm 47.744, p=0.000$ ) increased, while TOS (from 9.720 \pm 0.878 to $6.569 \pm 0.398, p=0.000$ ), OSI (from $0.751 \pm 0.104$ to $0.412 \pm 0.082$, $p=0.000$ ), MPO (from 70208.207 \pm 27307.594 to $42035.204 \pm 2484.022, p=0.012$ ), and MDA (from $121.657 \pm 7.633$ to $82.587 \pm 7.786, p=0.000$ ) levels statistically changed significantly (Table 1). No statistically significant difference was found between the treatment groups.

\begin{tabular}{|c|c|c|c|c|c|c|}
\hline $\begin{array}{l}\text { Experimental } \\
\text { Groups } n=8\end{array}$ & TAS (mmol/L) & TOS ( $\mu \mathrm{mol} / \mathrm{L})$ & $\begin{array}{c}\text { OSI } \\
\text { (arbitrary unit) }\end{array}$ & $\begin{array}{c}\text { SOD } \\
\text { (U/mg protein) }\end{array}$ & $\begin{array}{c}\text { MPO } \\
\text { (U/g protein) }\end{array}$ & $\begin{array}{c}\text { MDA } \\
\text { ( } \mu \mathrm{mol} / \mathrm{g} \text { protein) }\end{array}$ \\
\hline $\begin{array}{l}\text { Group S } \\
\text { (Sham kontrol) }\end{array}$ & $2.076 \pm 0.326$ & $6.546 \pm 0.398$ & $0.322 \pm 0.052$ & $478.139 \pm 82.335$ & $39430.418 \pm 5647.174$ & $77.734 \pm 7.394$ \\
\hline $\begin{array}{l}\text { Group R-IR } \\
\text { (Renal ischemia/ } \\
\text { reperfusion) }\end{array}$ & $1.311 \pm 0.167$ & $9.721 \pm 0.878$ & $0.751 \pm 0.104$ & $262.909 \pm 13.745$ & $70208.207 \pm 27307.594$ & $121.658 \pm 7.633$ \\
\hline $\begin{array}{l}\text { Group p-CA } \\
\text { (Renal ischemia/ } \\
\text { reperfusion+ } \\
50 \mathrm{mg} / \mathrm{kg} \mathrm{p-CA} \text { ) }\end{array}$ & $1.829 \pm .0 .282$ & $7.352 \pm 0.643$ & $0.412 \pm 0.082$ & $408.016 \pm 38.015$ & $48426.019 \pm 3309.833$ & $85.901 \pm 7.741$ \\
\hline $\begin{array}{l}\text { Group IV } \\
\text { (Renal ischemia/ } \\
\text { reperfusion + } \\
100 \mathrm{mg} / \mathrm{kg} \text { p-CA) }\end{array}$ & $2.057 \pm 0.167$ & $6.569 \pm 0.398$ & $0.412 \pm 0.082$ & $445.378 \pm 47.744$ & $42035.204 \pm 2484.022$ & $82.587 \pm 7.786$ \\
\hline $\begin{array}{l}\text { p value } \\
\text { (Meaningful } \\
\text { intergroup } \\
\text { comparisons) }\end{array}$ & $\begin{array}{c}0.000 \text { (I-II) } \\
0.001 \text { (IIIIII) } \\
0.000 \text { (II-IV) }\end{array}$ & $\begin{array}{c}0.000(\mathrm{IIII}) \\
0.000(\mathrm{II}-\mathrm{III}) \\
0.000(\mathrm{II}-\mathrm{IV}) \\
0.009(\mathrm{IIII})\end{array}$ & $\begin{array}{c}0.000(I-I I) \\
0.000(I I-I I I) \\
0.000(I I-I V) \\
0.020(I-I I I)\end{array}$ & $\begin{array}{c}0.000(\mathrm{IIII}) \\
0.000(\mathrm{II}-\mathrm{III}) \\
0.000(\mathrm{II}-\mathrm{IV}) \\
0.002(\mathrm{IIIII})\end{array}$ & $\begin{array}{c}0.008(I-I I) \\
0.042(I I-I I I) \\
0.012(I I-I V) \\
0.049(I-I I I)\end{array}$ & $\begin{array}{c}0.000(\mathrm{IIII}) \\
0.000(\mathrm{II}-\mathrm{III}) \\
0.000(\mathrm{IIIV}) \\
0.046(\mathrm{IIII})\end{array}$ \\
\hline
\end{tabular}

\section{Discussion}

In the current study, the effect of $p-C A$ on R-IR induced oxidative damage in rats was investigated by biochemical methods. In line with the literature, TOS and OSI activities, which are indicators of reactive oxygen radicals, have been shown to be significantly increased in the R-IR. ${ }^{28,29}$ TOS is a marker of the cumulative effect of oxidants in tissue, plasma, or body fluids, while TAS is an indication of the cumulative effect of antioxidants. ${ }^{30}$ Oxidative stress status can be evaluated globally by measuring total antioxidant status (TAS) and total oxidative status (TOS). ${ }^{31,32}$ Recently, it has 
been published that OSI may only show oxidative status more accurately than TOS or TAS. ${ }^{33}$ The imbalance between oxidant species and antioxidant molecules is defined as "oxidative stress". ${ }^{0}$ Assessment of TOS, TAS, and OSI contributes to the oxidative stress index. When oxidative stress indicator OSI, ${ }^{34}$ which shows a redox balance between oxidation and antioxidation, was assessed, an increase in oxidation in R-IR was detected, which was again found to approach baseline values in the treatment groups.

Cell damage is further increased by MDA formation. Another oxidative stress marker, MPO, reacts readily with a variety of biological molecules, leading to tissue damage. 16,35,36 In our study, these parameters increased in R-IR groups but decreased dose-dependently with p-CA administration.

It is known that there are various antioxidant defense mechanisms that remove the harmful effects of toxic oxidants in tissues. One of the role of antioxidants is to protect cell membrane lipids as well as target molecules against oxidation. ${ }^{37}$ Oxidant/antioxidant balance shifting in favor of oxidants leads to oxidative tissue damage. ${ }^{37}$ Glutathione (GSH), SOD, and catalase (CAT); prevents damage against ROS-dependent lipid peroxidation. ${ }^{38}$ Various enzymatic antioxidants, such as SOD and CAT activities, increase to eliminate ROS, therefore, decrease ischemic damage. ${ }^{10}$ In one study, SOD significantly reduced in the R-IR model. ${ }^{18}$ In our study, it was also shown that decreased SOD levels in the R-IR were increased in the p-CA treated groups, hence, decreased oxidative stress.

P-CA is a phenolic acid that is commonly found in plants and forms part of the human diet.39 Phenolic acid sources include peanut, tea, coffee, wine, and chocolate. ${ }^{40}$ The antioxidative mechanism of phenolic acid involves the binding of metal ions, the upregulation of ROS or other precursors and the endogenous antioxidant enzyme, or the repair of oxidative damage in biomolecules. ${ }^{41}$ p-CA (4-hydroxycinnamic acid) is produced by plants as secondary metabolites. ${ }^{42} \mathrm{p}$-CA and its derivatives play an important role in situations such as infection, food insufficiency, and injury. ${ }^{42}$ Its effects on the prevention of platelet aggregation have been reported as well as its antidiabetic, antihyperlipidemic, anticancer, antimicrobial, anti-inflammatory, anti-ulcer, anxiolytic, antipyretic, analgesic, anti-arthritic, antioxidant, and neuroprotective effects. ${ }^{43-45}$ In a study conducted, the level of MDA decreased significantly with the application of $p-\mathrm{CA}^{46}$ and increased SOD, CAT, and GSH levels in the damage groups. Another study demonstrated that $p$-CA has a protective effect against myocardial infarct size in rats. ${ }^{47}$ The antioxidant effect of $p$-CA has been shown via TAS and TOS. ${ }^{48} \mathrm{p}$-CA has been shown to improve recovery in rat hearts with increasing antioxidants such as SOD, GSH, and CAT and decreasing MDA in oxidative stress induced by doxorubicin. ${ }^{43}$ ROS formation and destruction in healthy cells are protected by a radical scavenger system containing antioxidants such as CAT, SOD, and GSH. ${ }^{49}$ Oxidative stress may be a consequence of increased ROS formation and/or decreased antioxidant defence. . $^{50,51}$

P-CA has been shown to reduce inflammation and lipopolysaccharide-induced depressive symptoms in rats. ${ }^{52}$ The protective effect has been shown in mice by increasing the antioxidant level of $p$-CA in a carbon tetrachloride-induced hepatotoxicity model. ${ }^{53}$ It has been shown that $p$-CA also increases antioxidants in the rat heart tissue. ${ }^{54} \mathrm{p}$-CA has been shown to reduce cytotoxicity and oxidative stress induced by glyoxal or methylglyoxal. ${ }^{55} \mathrm{p}$-CA inhibits lipid peroxidation with its antioxidant properties in bovine aortic endothelial cells exposed to high glucose and arachidonic acid. ${ }^{56} \mathrm{p}$-CA has been shown to suppress lung inflammation due to cigarette smoke in rats. ${ }^{57}$
Sakarya Medical Journal 2018;8(3):625-631

TANYELi et al. P-Coumaric Acid in Experimental Renal Ischemia-Reperfusion Mode 
p-CA has been shown to improve inflammation and reduce cartilage and bone erosion in rats with rheumatoid arthritis model. ${ }^{58} \mathrm{p}$-CA has also been shown to reduce the hippocampal neurodegeneration progress with its antioxidant and anti-inflammatory activities in the brain of diabetic rats. ${ }^{59}$ It has been shown that $p$-CA suppresses the inflammation caused by monosodium urate crystals in rats. ${ }^{60} \mathrm{P}$-CA has been shown the immunomodulatory and anti-inflammatory effect on experimental inflammation in rats. ${ }^{61}$

In this study, oxidant-antioxidant and inflammation parameters in the R-IR injury model using $\mathrm{p}$-CA were examined by biochemical method. The effect of $\mathrm{p}$-CA on R-IR injury and the oxidative stress and inflammation process during IR have not been studied in the literature. In this context, by showing the effects of $p$-CA on oxidant-antioxidant parameters and inflammation process in the R-IR model, this research aimed to fill the gap in the literature and lead the future studies to be conducted in this field.

\section{Acknowledgement}

We would like thanks to Kardelen Erdogan and Yaylagulu Yaman, undergraduates of Ataturk University Nursing Faculty, for their effort, help and support during the experiment. 
1. Malek M, Nematbakhsh M. Renal ischemia/reperfusion injury; from pathophysiology to treatment. J Renal Inj Prev, 2015; 4: 20-27.

2. Rovcanin B, Medic B, Kocic G, Cebovic T, Ristic M, Prostran M. Molecular Dissection of Renal Ischemia-Reperfusion: Oxidative Stress and Cellular Events. Curr Med Chem, 2016; 23: 1965-1980.

3. Xue L, Xie K, Han X, Yang Z, Qiu J, Zhao Z, Bao T. Detrimental functions of IL-17A in renal ischemia-reperfusion injury in mice. J Surg Res, 2011; 171: 266-274.

4. Eltzschig HK, Eckle T. Ischemia and reperfusion--from mechanism to translation. Nat Med, 2011; 17: 1391-1401.

5. Lameire NH, Bagga A, Cruz D, De Maeseneer J, Endre Z, Kellum JA, Liu KD, Mehta RL, Pannu N, Van Biesen W, Vanholder R. Acute kidney injury: an increasing global concern. Lancet, 2013; 382: 170-179.

6. Tas Hekimoglu A, Toprak G, Akkoc H, Evliyaoglu O, Ozekinci S, Kelle I. Oxytocin ameliorates remote liver injury induced by renal ischemia-reperfusion in rats. Korean J Physiol Pharmacol, 2013; 17: 169-173.

7. Chawla LS, Kimmel PL. Acute kidney injury and chronic kidney disease: an integrated clinical syndrome. Kidney Int, 2012; 82: 516-524.

8. Jang HR, Ko GJ, Wasowska BA, Rabb H. The interaction between ischemiareperfusion and immune responses in the kidney. J Mol Med (Berl), 2009; 87: 859-864.

9. Stroo I, Stokman G, Teske GJ, Raven A, Butter LM, Florquin S, Leemans JC. Chemokine expression in renal ischemia/reperfusion injury is most profound during the reparative phase. Int Immunol, 2010; 22: 433-442.

10. Carden DL, Granger DN. Pathophysiology of ischaemia-reperfusion injury. J Pathol, 2000;190: 255-266.

11. Lee DM, Hoffman WH, Carl GF, Khichi M, Cornwell PE. Lipid peroxidation and antioxidant vitamins prior to, during, and after correction of diabetic ketoacidosis. J Diabetes Complications, 2002; 16: 294-300.

12. Vaghasiya JD, Sheth NR, Bhalodia YS, Jivani NP. Exaggerated liver injury induced by renal ischemia reperfusion in diabetes: effect of exenatide. Saudi J Gastroenterol, 2010;16: 174-180.

13. Jang HS, Han JH, Jeong JY, Sohn UD. Protective Effect of ECQ on Rat Reflux Esophagitis Model. Korean J Physiol Pharmacol, 2012; 16: 455-462.

14. Jung J, Nam Y, Sohn UD. Inhibitory Effects of ECQ on Indomethacin-Induced Gastric Damage in Rats. Korean J Physiol Pharmacol, 2012; 16: 399-404.

15. Girotti AW. Lipid hydroperoxide generation, turnover, and effector action in biological systems. J Lipid Res, 1998;39: 1529-1542.

16. Lavelli V, Peri C, Rizzolo A. Antioxidant activity of tomato products as studied by model reactions using xanthine oxidase, myeloperoxidase, and copperinduced lipid peroxidation. J Agric Food Chem, 2000;48: 1442-1448.

17. Bradley PP, Priebat DA, Christensen RD, Rothstein G. Measurement of cutaneous inflammation: estimation of neutrophil content with an enzyme marker. J Invest Dermatol, 1982; 78: 206-209.

18. Zhao Z, Gong S, Wang S, Ma C. Effect and mechanism of evodiamine against ethanol-induced gastric ulcer in mice by suppressing Rho/NF-small ka, CyrillicB pathway. Int Immunopharmacol, 2015; 28: 588-595.

19. El-Seedi HR, El-Said AM, Khalifa SA, Goransson U, Bohlin L, Borg-Karlson AK, Verpoorte R. Biosynthesis, natural sources, dietary intake, pharmacokinetic properties, and biological activities of hydroxycinnamic acids. J Agric Food Chem, 2012; 60: 10877-10895.

20. Yoon SA, Kang SI, Shin HS, Kang SW, Kim JH, Ko HC, Kim SJ. p-CA modulates glucose and lipid metabolism via AMP-activated protein kinase in $\mathrm{L} 6$ skeletal muscle cells. Biochem Biophys Res Commun, 2013; 432: 553-557.

21. Kilic I, Yesiloglu Y. Spectroscopic studies on the antioxidant activity of $p$-CA. Spectrochim Acta A Mol Biomol Spectrosc, 2013; 115: 719-724.

22. Kadoma $\mathrm{Y}$, Fujisawa $\mathrm{S}$. A comparative study of the radical-scavenging activity of the phenolcarboxylic acids caffeic acid, p-CA, chlorogenic acid and ferulic acid, with or without 2-mercaptoethanol, a thiol, using the induction period method. Molecules, 2008; 13: 2488-2499.

23. Yue $Y$, Shen $P, X u Y$, Park $Y$. p-CA improves oxidative and osmosis stress responses in Caenorhabditis elegans. J Sci Food Agric, 2018.

24. Navaneethan $D$, Rasool MK. An experimental study to investigate the impact of $\mathrm{p}-\mathrm{CA}$, a common dietary polyphenol, on cadmium chloride-induced renal toxicity. Food Funct, 2014; 5: 2438-2445.

25. Ohkawa $\mathrm{H}$, Ohishi $\mathrm{N}$, Yagi K. Assay for lipid peroxides in animal tissues by thiobarbituric acid reaction. Analytical biochemistry, 1979; 95: 351-358.

26. Erel O. A new automated colorimetric method for measuring total oxidant status. Clinical biochemistry, 2005; 38: 1103-1111.

27. Sun Y, Oberley LW, Li Y. A simple method for clinical assay of superoxide dismutase. Clinical chemistry, 1988; 34: 497-500.

28. Kulshreshtha R, Ferracin M, Wojcik SE, Garzon R, Alder H, Agosto-Perez F), Davuluri R, Liu CG, Croce CM, Negrini M, Calin GA, Ivan M. A microRNA signature of hypoxia. Mol Cell Biol, 2007; 27: 1859-1867.

29. Kulshreshtha R, Davuluri RV, Calin GA, Ivan M. A microRNA component of the hypoxic response. Cell Death Differ, 2008; 15: 667-671.

30. Jansen EH, Ruskovska T. Comparative Analysis of Serum (Anti)oxidative Status Parsmall a, Cyrillicmeters in Healthy Persons. Int J Mol Sci, 2013;14: 6106-6115.

31. Erel O. A new automated colorimetric method for measuring total oxidant status. Clin Biochem, 2005;38: 1103-1111.

32. Erel O. A novel automated direct measurement method for total antioxidant capacity using a new generation, more stable ABTS radical cation. Clin Biochem, 2004; 37: 277-285.
33. Harma M, Harma M, Erel O. Increased oxidative stress in patients with hydatidiform mole. Swiss Med Wkly, 2003; 133: 563-566.

34. Davies GR, Simmonds NJ, Stevens TR, Grandison A, Blake DR, Rampton DS. Mucosal reactive oxygen metabolite production in duodenal ulcer disease. Gut, 1992; 33: 1467-1472.

35. Gutteridge JM. Lipid peroxidation and antioxidants as biomarkers of tissue damage. Clin Chem, 1995;41: 1819-1828.

36. Abbas AM, Sakr HF. Effect of selenium and grape seed extract on indomethacin-induced gastric ulcers in rats. J Physiol Biochem, 2013; 69: 527-537.

37. Rangan U, Bulkley GB. Prospects for treatment of free radical-mediated tissue injury. Br Med Bull, 1993; 49: 700-718

38. Liu YH, Zhang ZB, Zheng YF, Chen HM, Yu XT, Chen XY, Zhang X, Xie JH, Su ZQ, Feng XX, Zeng HF, Su ZR. Gastroprotective effect of andrographolide sodium bisulfite against indomethacin-induced gastric ulceration in rats. Int Immunopharmacol, 2015; 26: 384-391.

39. Scalbert A, Williamson G. Dietary intake and bioavailability of polyphenols. J Nutr, 2000; 130: 2073-2085.

40. King A, Young G. Characteristics and occurrence of phenolic phytochemicals. J Am Diet Assoc, 1999; 99: 213-218.

41. Ursini F, Tubaro F, RongJ, Sevanian A. Optimization of nutrition: polyphenols and vascular protection. Nutr Rev, 1999; 57: 241-249.

42. Dixon RA. Natural products and plant disease resistance. Nature, 2001; 411 843-847.

43. Abdel-Wahab MH, El-Mahdy MA, Abd-Ellah MF, Helal GK, Khalifa F, Hamada $\mathrm{FM}$. Influence of $\mathrm{p}$-CA on doxorubicin-induced oxidative stress in rat's heart. Pharmacol Res, 2003; 48: 461-465.

44. Amalan V, Vijayakumar N, Indumathi D, Ramakrishnan A. Antidiabetic and antihyperlipidemic activity of $p$-CA in diabetic rats, role of pancreatic GLUT 2 In vivo approach. Biomed Pharmacother, 2016; 84: 230-236.

45. Guven M, Aras AB, Akman T, Sen HM, Ozkan A, Salis O, Sehitoglu I, Kalkan $\mathrm{Y}$, Silan C, Deniz M, Cosar M. Neuroprotective effect of $\mathrm{p}-\mathrm{CA}$ in rat model of embolic cerebral ischemia. Iran J Basic Med Sci, 2015; 18: 356-363.

46. Mestrovic J, Pogorelic Z, Drmic-Hofman I, Vilovic K, Todoric D, Popovic M. Protective effect of urapidil on testicular torsion-detorsion injury in rats. Surg Today, 2017; 47: 393-398.

47. Stanely Mainzen Prince P, Roy AJ. p-CA attenuates apoptosis in isoproterenol-induced myocardial infarcted rats by inhibiting oxidative stress. Int J Cardiol, 2013; 168: 3259-3266.

48. Koyuncu I, Gonel A, Akdag A, Yilmaz MA. Identification of phenolic compounds, antioxidant activity and anti-cancer effects of the extract obtained from the shoots of Ornithogalum narbonense L. Cell Mol Biol (Noisy-le-grand) 2018; 64: 75-83

49. Gulcin I. Antioxidant and antiradical activities of L-carnitine. Life Sci, 2006 78: 803-811.

50. Buyukokuroglu ME, Gulcln I, Oktay M, Kufrevioglu OI. In vitro antioxidant properties of dantrolene sodium. Pharmacol Res, 2001; 44: 491-494.

51. Gulcin I, Buyukokuroglu ME, Oktay M, Kufrevioglu OI. Antioxidant and anagesic activities of turpentine of Pinus nigra Arn. subsp. pallsiana (Lamb) Holmboe. J Ethnopharmacol, 2003; 86: 51-58.

52. Lee S, Kim HB, Hwang ES, Kim ES, Kim SS, Jeon TD, Song MC, Lee JS, Chung MC, Maeng S, Park JH. Antidepressant-like Effects of p-CA on LPS-induced Depressive and Inflammatory Changes in Rats. Exp Neurobiol, 2018; 27 ; 189-199.

53. Song A, Ko HJ, Lai MN, Ng LT. Protective effects of Wu-Ling-Shen (Xylaria nigripes) on carbon tetrachloride-induced hepatotoxicity in mice. Immunopharmacol Immunotoxicol, 2011; 33: 454-460.

54. Yeh CT, Ching LC, Yen GC. Inducing gene expression of cardiac antioxidant enzymes by dietary phenolic acids in rats. J Nutr Biochem, 2009; 20: 163 171.

55. Maruf AA, Lip H, Wong H, O'Brien PJ. Protective effects of ferulic acid and related polyphenols against glyoxal- or methylglyoxal-induced cytotoxicity and oxidative stress in isolated rat hepatocytes. Chem Biol Interact, 2015; 234: 96-104.

56. Lee SJ, Mun GI, An SM, Boo YC. Evidence for the association of peroxidase with the antioxidant effect of $\mathrm{p}-\mathrm{CA}$ in endothelial cells exposed to high glucose plus arachidonic acid. BMB Rep, 2009; 42: 561-567.

57. Kim W, Lim D, Kim J. p-CA, a Major Active Compound of Bambusae Caulis in Taeniam, Suppresses Cigarette Smoke-Induced Pulmonary Inflammation. Am J Chin Med, 2018; 46: 407-421.

58. Neog MK, Joshua Pragasam S, Krishnan M, Rasool M. p-CA, a dietary polyphenol ameliorates inflammation and curtails cartilage and bone erosion in the rheumatoid arthritis rat model. Biofactors, 2017; 43: 698-717.

59. Abdel-Moneim A, Yousef Al, Abd El-Twab SM, Abdel Reheim ES, Ashour MB. Gallic acid and $p$-CA attenuate type 2 diabetes-induced neurodegeneration in rats. Metab Brain Dis, 2017;32: 1279-1286.

60. Pragasam SJ, Rasool M. Dietary component p-CA suppresses monosodium urate crystal-induced inflammation in rats. Inflamm Res, 2013; 62: 489-498.

61. Pragasam SJ, Venkatesan V, Rasool M. Immunomodulatory and anti-inflammatory effect of $p$-CA, a common dietary polyphenol on experimental inflammation in rats. Inflammation, 2013; 36: 169-176. 